Kaganga : Jurnal Pendidikan Sejarah dan Riset Sosial Humaniora.

Volume 1, Nomor 2, Desember 2018

e-ISSN : 2598-4934

$p$-ISSN : 2621-119X

DOI : https://doi.org/10.31539/kaganga.v1i2.387

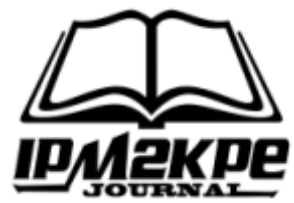

\title{
PENINGKATAN KEMAMPUAN PENGENALAN SEJARAH ISLAM MELALUI MEDIA SCREABBLE BAGI ANAK USIA DINI
}

\author{
Adi Priyanto \\ STKIP Yayasan Abdi Pendidikan Payakumbuh \\ adi.priyanto_se@yahoo.co.id
}

\begin{abstract}
ABSTRAK
Penelitian ini bertujuan untuk mendeskripsikan proses dan hasil pembelajaran mengenai media screabble untuk menstimulasi pengenalan sejarah islam bagi anak di taman kanak-kanak usia 5-6 tahun. Penelitian ini menggunakan penelitian action reseach pada kelompok B di TK Nurul Hidayah Sumatera Barat. Metode yang digunakan adalah metode Kemmis dan Taggart yang terdiri dari perencanaan, tindakan, observasi, dan refleksi. Teknik pengumpulan data yang digunakan adalah observasi, wawancara, catatan lapangan, instrumen pemantau tindakan dan dokumentasi. Analisis data disajikan secara kuantitatif dan kualitatif. Hasil data secara kuantitatif menunjukan bahwa kemampuan pengenalan sejarah islam anak dapat meningkat setelah dilakukan tindakan melalui media screabble. Hal ini dapat dilihat dari hasil penelitian yang menyebutkan bahwa rata-rata kelas pada pra tindakan sebesar 50.27\%. Setelah dilakukan tindakan dalam siklus I meningkat rata-rata kelas menjadi $69 \%$ dan siklus II meningkat sebesar $85.95 \%$. Berdasarkan hasil penelitian dapat disimpulkan media screabble mampu meningkatkat kemampuan mengenal sejarah agama islam anak.
\end{abstract}

Kata Kunci : Sejarah Islam. Media Screabble

\section{ABSTRACT}

The study aims to describe the process and learning achievement through scrabble media to stimulate the students in knowing the history of Islam to kindergarten students age 5-6 years old. The research was an action reseach on group B at TK Nurul Hidayah West Sumatera. The method of the study was Kemmis and Tagart method by applying some steps including planning, action, observation, and reflection. The techniques to collect the data were observation, interview, field noting, instruments of action observer and documentation. The data were analyzed through quantitative and qualitative method. The results in quantitative showed that the students ability at knowing the history of Islam was improved after treated by scrabble. It can be proved by the average of the percentage before treatment was 50.27\%. After some treatments in cycle I, it was improved to $69 \%$ and it was also improved in cycle II for $85.95 \%$. Based on the result, it can be concluded that scrabble can improve kindergarten students ability at knowing the history of Islam.

Krewords: The history of Islam, Scrabble Media 


\section{PENDAHULUAN}

Dunia pendidikan sekarang ini, peranan guru bukan hanya sekedar mengajar tetapi meningkat menjadi direktur belajar (director of learning). Artinya, setiap guru diharapkan mampu untuk mengarahkan dan meningkatkan minat dan kebiasaaan dalam kegiatan belajar siswa agar tercapai keberhasilan belajar (kinerja akademik) sebagaimana yang telah ditetapkan dalam sasaran kegiatan proses belajar mengajar.

Kelas yang ideal, siswa bekerja dalam kelompok kecil atau bekerja mandiri, dalam rangka mempelajari teori dan contoh, mengerjakan tugastugas, menggunakan alat-alat bantu, alat komputasi seperti kalkulator atau komputer, mencari atau memilih pustaka dan mempelajarinya. Siswa dalam bekerja itu diharapkan bertukar pikiran dengan sesama siswa atau bertukar pikiran dengan guru, dan mencatat hal-hal penting yang diperbuat atau diperolehnya. Guru diharapkan dapat mengajak siswa secara keseluruhan untuk melakukan diskusi kelas, atau memberikan pengarahan umum, bertugas sebagai fasilitator baik secara klasikal atau individual.

Pendidikan Anak Usia Dini merupakan pendidikan yang menjadi gerbang awal memasuki pendidikan selanjutnya. Pendidikan sebaiknya dilaksanakan sedini mungkin sehingga pendidikan tersebut dapat menjadi investasi di masa depan. Pendidikan anak usia dini merupakan upaya pengembangan yang ditujukan untuk anak-anak sejak lahir hingga usia delapan tahun, dilakukan melalui penyediaan rangsangan pendidikan untuk mendorong pertumbuhan fisik dan psikologis sehingga anak-anak dapat bersekolah memasuki pendidikan lanjutan.

Periode ini merupakan periode yang kondusif untuk mengembangkan berbagai kemampuan fisik, kognitif, linguistik, sosio-emosional dan spiritual. Pada usia ini adalah zaman keemasan dimana lingkungan dapat mendorong dan merangsang semua aspek perkembangan anak secara optimal. Stimulasi atau rangsangan yang diberikan terhadap anak usia dini haruslah tepat.

Guru tidak hanya sekedar menyampaikan materi pelajaran kepada siswa namun harus merupakan seluruh kegiatan dan tindakan yang diupayakan oleh guru untuk terjadinya proses belajar sesuai dengan tujuan yang telah dirumuskan. Guru harus memiliki ketarmpilan mengajar, mengelola tahapan pembelajaran, memanfaatkan metode, menggunakan media, dan mengalikasikan waktu. Interaksi belajar mengajar, guru memegang kendali utama untuk keberhasilan tercapainya tujuan.

Belajar adalah suatu proses perubahan tingkah laku individu melalui interaksi dengan lingkungan. Slavin (2011) mengemukakan belajar merupakan usaha yang dilakukan seseorang melalui interaksi dengan lingkunganya untuk merubah perilakunya. Kegiatan belajar adalah perubahan perilaku yang relatif permanen pada diri orang yang belajar. 
Belajar adalah proses perubahan tingkah laku seseorang berdasarkan praktek. Artinya dalam belajar diharapkan perolehan pemecahan masalah. Belajar menurut Hill (2007) belajar terjadi disebabkan pengalaman yang menyebabkan perubahan relatif permanen dalam pengetahuan individu. Menurut Good dan Brophy (1990), dimensi belajar mengacu pada cara pendekatan belajar dalam membuat tugas, belajar hapalan digunakan untuk mencoba mengingat informasi baru tanpa menghubungkan ide dengan objek yang sudah diketahui, dan belajar mengerti bertahan lebih lama.

$\begin{array}{ccr}\begin{array}{c}\text { Winkel } \\ \text { merupakan }\end{array} & \text { suatu } & \begin{array}{r}\text { belajar } \\ \text { aktifitas }\end{array}\end{array}$
mental/fsikis, yang berlangsung dalam interaksi dengan lingkungan, yang menghasilkan suatu perubahanperubahan dalam pengetahuan dan pemahaman, keterampilan, dan nilai sikap. Perubahan yang terjadi relative konstan dan berbekas.

Permainan scrabble dilakukan oleh beberapa orang dan memiliki nilai point, hal ini yang dinyatakan oleh Hinebaugh (2009) "Scrabble is a board game and the game construct words played 2 or 4 people who accumulate points based on the value of a word formed from pieces of letters on the game board boxes (15 columns and 15 rows)."

Pernyataan ini dapat diartikan bahwa Scrabble adalah permainan papan dan permainan menyusun kata yang dimainkan 2 atau 4 orang yang mengumpulkan poin berdasarkan nilai kata yang dibentuk dari keping huruf diatas papan permainan berkotakkotak (15 kolom dan 15 baris). Scrabble adalah sata satu permainan papan intelektual yang paling populer di dunia karena sifat gaming-nya yang menuntut pemain menguasai kosa kata yang luas.

Scrabble merupakan permainan yang dimainkan sendiri, atau yang kadang disebut Solitaire. Lalu, pemainnya mengumpulkan poin berdasarkan nilai kata yang dibentuk dari keping huruf di atas papan permainannya. Maksud poin-poin disini adalah jumlah keseluruhan poin yang didapat pemain saat membentuk suatu kata, jadi setiap tile (kepingan huruf) memiliki poin yang berbeda. Sebagai penjelas, huruf-huruf vokal (A, I, U, E, O) dan huruf-huruf konsonan yang sering digunakan seperti huruf $\mathrm{L}, \mathrm{N}, \mathrm{R}, \mathrm{S}$, dan $\mathrm{T}$ memiliki poin 1 . Kemudian, huruf $\mathrm{D}$ dan $\mathrm{G}$ memiliki poin 2. Lalu, huruf B, $\mathrm{C}, \mathrm{M}$, dan $\mathrm{P}$ memiliki poin 3 . Selanjutnya huruf F, H, V, W dan Y memiliki poin 4.

Seterusnya adalah huruf premium, diartikan sebagai huruf yang memiliki poin tinggi yaitu $\mathrm{K}$ dengan 5 poin, $\mathrm{J}$ dan $\mathrm{X}$ dengan poin 8 dan terakhir adalah huruf $\mathrm{Z}$ dan $\mathrm{Q}$ yang memiliki poin 10 .

\section{METODE PENELITIAN}

Metode penelitian ini adalah penelitian tindakan. Wijaya (2001) menjelaskan bahwa penelitian tindakan merupakan salah satu cara strategis bagi pendidik untuk memperbaiki dan / atau memperbaiki 
layanan pendidikan dalam konteks pembelajaran di kelas.

Teknik pengumpulan data yang digunakan dalam penelitian ini adalah non test. Teknik non test yang digunakan untuk memperoleh data tentang pelaksanaan tindakan dan data kemampuan berbicara anak (variabel terkait) adalah observasi. Observasi yang digunakan adalah observasi partisipan, dimana pengamat berpartisipasi dalam kegiatan yang dilakukan oleh subyek yang diteliti atau diobservasi seolah-olah mereka adalah bagian dari mereka.

Perancangan intervensi/desain tindakan siklus penelitian ini menggunakan model Kemmis dan MC Taggart berdasarkan: (1) perencanaan, (2) tindakan / observasi, (3) refleksi. Teknik analisis data kuantitatif dan kualitatif. Analisis data kuantitatif disajikan dalam bentuk tabel dan grafik. Sedangkan analisis data kualitatif menggunakan metode Miles dan Haberman (1990), yang terdiri dari tahap reduksi data, tampilan data dan verifikasi data

\section{HASIL DAN PEMBAHASAN}

Belajar adalah suatu proses perubahan tingkah laku individu melalui interaksi dengan lingkungan. Kegiatan belajar adalah perubahan perilaku yang relatif permanen pada diri orang yang belajar. Belajar adalah proses perubahan tingkah laku seseorang berdasarkan praktek. Artinya dalam belajar diharapkan perolehan pemecahan masalah.

Dimensi belajar mengacu pada cara pendekatan belajar dalam membuat tugas, belajar hapalan digunakan untuk mencoba mengingat informasi baru tanpa menghubungkan ide dengan objek yang sudah diketahui, dan belajar mengerti bertahan lebih lama. Pada saat memasuki usia sekolah TK anak mulai memiliki kesanggupan untuk mengenal lingkungan dan sejarah agama sesuai dengan tahapan usia.

\section{Pra siklus}

Assesmen awal pada kemampuan mengenal sejarah islam anak melalui kegiatan bermain screablle menunjukan bahwa masih banyak anak yang kemampuan mengenal sejarah islam. Berikut hasil Assesmen awal kemampuan anak dapat dilihat pada grafik di bawah ini :

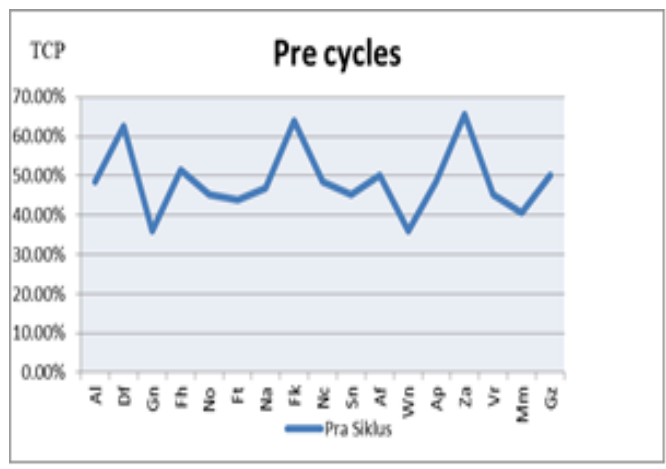

Graph 1: Pre-Cycle hasil kemampuan mengenal Sejarah Islam

Berdasarkan visualisasi grafik diatas menunjukkan bahwa masih rendahnya kemampuan mengenal sejarah islam, terlihat pada taraf penilaian belum muncul, dan mulai muncul sedangkan sering muncul dan konsisten masih sedikit anak yang mampu menceritakan sejarah islam yang telah di ceritakan oleh guru pada tahap penilaian ini. 
Dari data pra siklus menunjukkan nilai awal anak dilihat dari persentase skor awal sebagai berikut: Al 50\%, Df 60\%, Gn 40\%, Fh $55 \%$, No $45,31 \%$, Ft $43,75 \%$, Na $46,86 \%$, Fk $64,06 \%$ Nc $45,31 \%$, Sn $50 \%$, Af $50 \%$, Wn 35,94\%, Ap 48,44\%, Za $65,63 \%$, Vr 50\%, Mm $50 \%$, dan $\mathrm{Gz} 50 \%$. Sedangkan ratarata persentase sekitar $50.5 \%$.

Dengan demikian data yang menunjukkan persentase siswa TK kelas B pada pre-cycle yang memiliki persentase lebih tinggi dari rata-rata anak lain hanya sebesar 6 (enam) anak. Persentase tertinggi dari keseluruhan aspek tertinggi dari skor pra-siklus pra-siklus $65,63 \%$ dimiliki oleh Za. Berdasarkan data pengamatan pada pra-siklus di atas, yang telah terpapar melalui data kualitatif dan kuantitatif, sehingga peneliti dan kolumnis menyimpulkan tindakan yang diperlukan dirancang dan diharapkan dapat meningkatkan kemampuan pengenalan sejarah islam bagi anak usia dini.

\section{Siklus I}

Selanjutnya peneliti memberikan tindakan berupa stimulasi menggunakan media screable kepada anak usia dini. Pada proses kegiatan stimulasi bermain screable ada beberapa tahapan kegiatan yang harus diperhatikan a) penyesuaian dengan tema yang sedang berlangsung, b) mendengarkan cerita yang disampaikan, c) bermain screablle dengan menyusun kata yang sesuai dengan arahan guru. Kelebihan yang dirasakan berdasarkan penelitian ini adalah anak sangat menyenangi proses kegiatan bermain screable sehingga peneliti menemukan berbagai hal yang sangat menarik dan menunjukkan peningkatan dalam pengenalan sejarah islam.

\section{Graph 2: Grafik hasil kemampuan pengenalan sejarah islam}

Berdasarkan visualisasi grafis, hal ini menunjukkan peningkatan kemampuan yang dialami selama siklus 1. Ada 6 anak dengan persentase $50,50 \%$ adalah Al,Sn,Vr,Mm,Gz Sedangkan pada siklus 1 ada 8 anak yang memiliki persentase di atas kelas rata-rata $69 \%$ adalah Al 75\%, Df 84,38\%, Fh 80\%, $\mathrm{Na} 70 \%$, Af $78 \%$, Za $81,25 \%, \mathrm{Vr}$ $75 \% \mathrm{Mm}$ 71,68\%. Dari jumlah tersebut hanya 5 (lima) anak yang mencapai skor persentase minimal $75 \%$ (TCP / level prestasi pembangunan), yaitu $\mathrm{Al} 75 \%$, Df $84,38 \%$, Fk 81,25\%, Za 81,5 dan Vr $75 \%$.

Dengan kata lain, hanya $29,41 \%$ siswa yang mencapai peningkatan TCP sebesar $75 \%$ dengan kriteria menurut Mills sebesar $71 \%$. Dengan demikian persentase perbaikan yang dijelaskan di atas menunjukkan bahwa masih ada hal-hal yang perlu ditingkatkan untuk memaksimalkan 
pencapaian kriteria keberhasilan. Oleh karena itu, perlu diimplementasikan siklus kedua sehingga akan memaksimalkan pembelajaran dalam meningkatkan kemampuan pengenalan sejarah islam

\section{Siklus II}

Pada proses kegiatan stimulasi anak melalui screable ada beberapa yang temuan, yaitu a) sikap anak, b) partisipasi anak. Temuan yang mengarah pada sikap anak yang muncul adalah : a) keterlibatan, yaitu saat bermain, anak menunjukkan keterlibatan, walaupun terkadang ada anak yang juga tidak ingin terlibat namun dengan arahan guru pada akhirnya anak ikut menikmati permainan, b) rasa ingin tahu, yaitu saat anak bertanya tentang langkah langkah permainan serta rasa tidak sabar menunggu giliran bermain, dan c) minat anak, saat mengikuti proses kegiatan bermain screabble sehingga anak dengan senang dan mudah mengenal cerita dari sejarah islam. Hal Ini terlihat dari grafik Hasil Prasiklus, siklus I dan Siklus II.

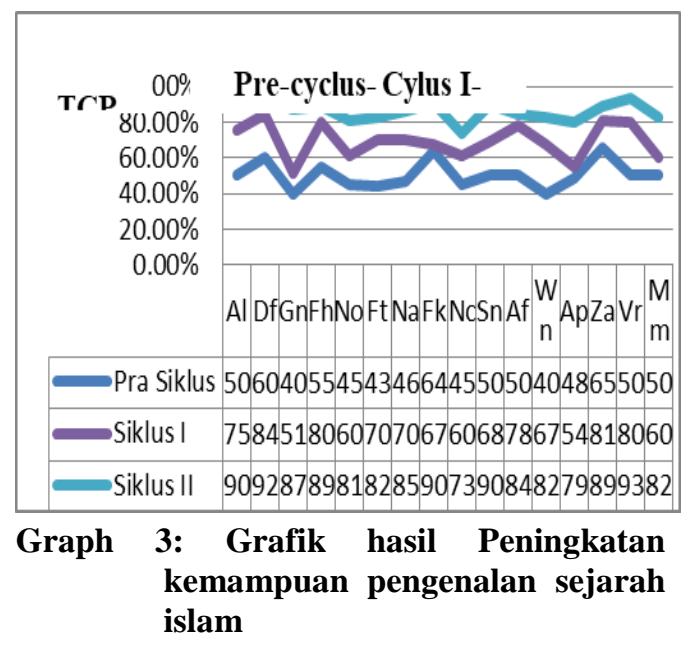

Berdasarkan grafik di atas dapat dijelaskan bahwa melalui kegiatan bermain screabble dapat meningkatkan kemampuan pengenalan sejarah islam. Hal ini terlihat melalui persentasi Pra-siklus dalam kegiatan bermain screabble menunjukkan $50,27 \%$ pengenalana sejarah nya berkembang, sedangkan di siklus I mengalami penurunan yaitu hanya $69 \%$ sehingga peneliti harus merumuskan siklus ke II. Pada siklus II guru dan peneliti memperbaiki dari berbagai kekurangan yang terjadi pada siklus I. Setelah dilaksanakan siklus II peneliti memperoleh $85,95 \%$, sehingga stimulasi screabble baru dapat dikatakan berhasil dan tidak melanjutkan pada siklus berikutnya. Dari kegiatan tersebut peneliti memperoleh berbagai temuan baik proses dan hasil.

Temuan pada proses partisipasi anak dalam kegiatan screablle yaitu : a) peran serta anak, yaitu anak dalam melakukan kegiatan tampak senang mengikuti arahan guru, serta mampu menyelesaikan tugas tertentu dalam proses permainannya. Di sini dapat di lihat tanggung jawab anak serta rasa percaya diri anak mulai nampak, b) respon anak, yaitu anak dalam mengikuti kegiatan bermain sangat senang, c) Perhatian anak, yaitu saat guru menjelaskan dan memberi panduan atau langkah-langkah dalam bermain, anak antusias mendengarkan serta mengikuti apa yang disampaikan oleh guru.

Temuan berikutnya ialah pada proses tindakan Guru, saat mengikuti kegiatan yaitu : a) Fasilitator, yaitu 
guru menyediakan bahan dan media yang diperlukan selama proses kegiatan. Guru juga memberi stimulus yang dapat berpengaruh pada perhatian serta minat anak dalam mengikuti kegiatan. b) Motivator, yaitu guru dapat memberikan semangat pada anak saat mengerjakan tugas maupun memberikan penguatan pada anak saat belum berhasil mengerjakan tugas, guru pun dapat memberikan penghargaan saat anak berhasil dalam mengerjakan tugas. c) Evaluator, yaitu guru bertugas mengevaluasi seluruh proses kegaiatan belajar menjagar dan memberikan assesment terhadap hasil kegiatan belajar dan bermain anak.

Tujuan pembelajaran sejarah islam akan tercapai dengan baik jika pendidik mampu mengaplikasikan metode dan media pembelajaran yang tepat dengan kebutuhan peserta didik. Metode merupakan alat untuk mencapai tujuan, hal ini berlaku baik bagi guru, dosen, pelatih, dan siswa. Makin baik metode itu, makin efektif pula pencapaian tujuan. Dengan memiliki pengertian secara umum mengenai sifat berbagai metode, baik mengenai kebaikanya akan lebih mudah untuk menetapkan metode yang akan dilaksanakan.

Dalam Al-Quran surah AlBaqarah ayat 132, Allah berfirman

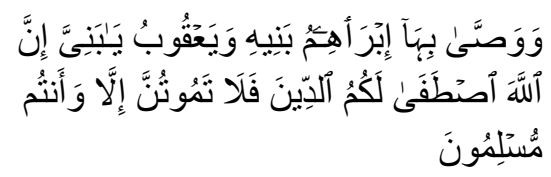

Artinya :"Nabi Ibrahim telah berwasiat kepada anak-anaknya, demikian pula Nabi Ya'kub, Ibrahim berkata : Sesungguhnya Allah telah memilih agama Islam sebagai agamamu, sebab itu janganlah kamu meninggal melainkan dalam memeluk agama Islam". (QS. Al-Baqarah, 2:132)

Nabi Isa juga membawa agama Islam, seperti dijelaskan dalam ayat yang berbunyi sebagai berikut:

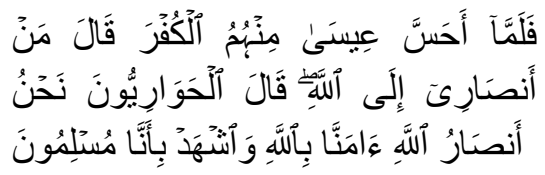

Artinya :"Maka ketika Nabi Isa mengetahui keingkaran dari mereka (Bani Israil) berkata dia : Siapakah yang akan menjadi penolongpenolongku untuk menegakkan agama Allah (Islam)? Para Hawariyin (sahabat beriman kepada Allah, dan saksikanlah bahwa sesungguhnya kami adalah orang-orang muslim" (QS. Ali Imran, 3:52).

Dengan demikian Islam adalah agama Allah yang diwahyukan kepada Rasul-rasul-Nya untuk diajarkankan kepada manusia. Dibawa secara berantai (estafet) dari satu generasi ke generasi selanjutnya dari satu angkatan ke angkatan berikutnya. Islam adalah rahmat, hidayat, dan petunjuk bagi manusia dan merupakan manifestasi dari sifat rahman dan rahim Allah swt.

Agama-agama selain Islam umumnya diberi nama yang dihubungkan dengan manusia yang mendirikan atau yang menyampaikan agama itu atau dengan tempat lahir agama bersangkutan seperti agama 
Budha (Budhism), agama Kristen (Christianity), atau agama Yahudi (Judaism). Nama agama yang disampaikan oleh Nabi Muhammad ini tidak dihubungkan dengan nama orang yang menyampaikan wahyu itu kepada manusia atau nama tempat agama itu mula-mula tumbuh dan berkembang.

Memahami ajaran Islam dengan sebaik-baiknya, merupakan komitmen umat Islam terhadap Islam. Komitmen tersebut intinya terdapat dalam QS. Al-Asr(103) yang berbunyi :

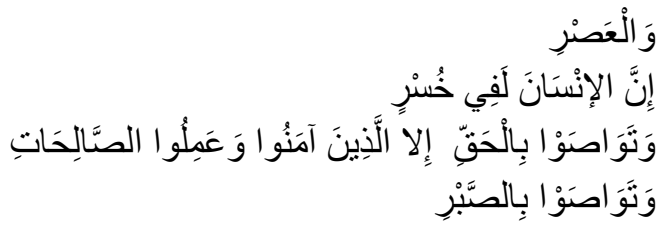

Artinya: Demi masa. (1) Sesungguhnya manusia itu benarbenar berada dalam kerugian, (2) kecuali orang-orang yang beriman dan mengerjakan amal saleh dan nasehat menasehati supaya menta'ati kebenaran dan nasehat menasehati supaya menetapi kesabaran.

Paterson (2010) Permainan scrabble merupakan permainan membaca yang menggunakan metode fonik yang merupakan salah satu metode membaca permulaan yang memulai dengan ejaan dari struktur terkecil yaitu huruf, suku kata, kata dan kalimat. Dari bagian ejaan terkecil (huruf) sampai menyatukan menjadi bagian yang terbesar (kalimat).

Pendapat Joe Edley (2009) menyatakan bahwa "Scrabble game is a game arrange letter tiles into a word above a rectangular board".
Permainan scrabble merupakan permainan menyusun kepingan huruf menjadi sebuah kata diatas sebuah papan berbentuk persegi empat. hal ini berarti bahwa Pemain menyebutkan kata yang mempunyai huruf awal yang sudah tersedia di papan kemudian berusaha menyusun kata secara mendatar atau menurun seperti tekateki silang. permainan ini tergolong jenis permainan konstruktif.

Permainan konstruktif menurut merupakan permainan bersifat membangun yang melibatkan pemakaian bahan-bahan untuk menciptakan sesuatu yang ada setelah permainan sudah diselesaikan. Selain itu, permainan konstruktif terjadi karena anak-anak melibatkan diri dalam suatu kreasi atau konstruktif suatu produk atau suatu pemecahan masalah ciptaan sendiri.

Pepen (2008) menyatakan manfaat media permainan Scrabble dilihat dari berbagai aspek, antara lain:

1. Kognitif, kemampuan mengetahui dan mengingat

2. Motorik, kemampuan mengkoordinasi-kan anggota tubuh seperti tangan dankaki

3. Logika, kemampuan berpikir secaratepat dan teratur

4. Emosional/Sosial, kemampuan merasa-kan dan menjalin hubungan interpersonal

5. Kreatif/Imajinatif, kemampuan meng-hasilkan ide sesuai dengan konteks

Permainan scrabble tidak hanya mengembangkan kemampuan bahasa anak, namun dengan bermain scrabble semua aspek perkembangan anak 
menjadi berkembang. Selain dapat mengembangkan aspek perkembangan anak, manfaat lain dari permainan scrabble yaitu (1) Strategy (2) Numeracy fast, (3) Improve memory.

Pernyataan ini dapat dijelaskan bahwa permainan scrabble bermanfaat untuk strategi yaitu melatih untuk mencari prediksi-prediksi yang harus di putuskan, sebab dalam permainan ini harus menentukan langkah mana yang harus diambil untuk mendapatkan gelar juara dalam permainan ini.

Manfaat berhitung cepat yaitu untuk melatih agar dapat berhitung dengan cepat, karena permaian ini menuntut untuk dapat menghitung nilai dari setiap langkah yang diambil, jadi semakin besar nilai yang didapat maka akan semakin besar kesempatan memenangkan permainan tersebut. Selanjutnya manfaat meningkatkan daya ingat membantu untuk meningkatkan daya ingatan, sebab di dalam permainan ini sangat di tuntut untuk dapat mengingat sebanyak mungkin kosa kata untuk dimainkan.

Manfaat media permainan Scrabble dapat dilakukan dalam situasi pembelajaran di kelas karena dalam proses pemanfaatan scrabble seorang guru terlebih dahulu menentukan media yang sesuai dengan tujuan pembelajaran setelah itu baru memanfaatkan media pada proses pembelajaran. Pemanfaatan media permainan Scrabble dalam proses pembelajaran digunakan untuk membantu anak mengembangkan membaca permulaan. Diharapkan dengan adanya media permainan
Scrabble dapat mengembangkan kemampuan membaca permualaan anak

\section{SIMPULAN}

Sejarah islam sangat penting bagi perkembangan musik anak-anak dan pendidikan di waktu pengalaman TK mereka pada usia 5-6 tahun. Meskipun guru TK memiliki kemampuan terbatas dalam memberikan media yang menarik, media screabble adalah salah satu media yang digunakan paling dominan di TK. Media bermain screabble sangat dianjurkan sebagai bahan dan proses pembelajaran di kelas TK. Screable adalah kegiatan yang dapat meningkatkan pengetahuan perkembangan. Guru tidak hanya menjadi spesialis musik tetapi juga guru kelas yang bertanggung jawab untuk pengembangan konsep sejarah islami anak-anak.

\section{DAFTAR PUSTAKA}

C.P. Hill. (2007). Saran-Saran Tentang Mengajarkan Sejarah. Jakarta: Perpustakaan Keguruan Kementrian P Dan K.

Geoffrey E., M. (1990). Action Reseach A Guide for the teacher researcher. USA Spinger.

Hinebaugh, J., P. (2009). A Board Game Education. (USA: Rowman \& Littlefield Education).

Edley., J. John D., W. (2009). Everyting Scrabble. New York: A Division Of Simon Shuster.Inc.

Kathy P. (2010) 3 Minutes Motivators (Sukses Memotivasi Dalam 3 Menit). Jakarta: Grasindo. 
Pepen S. Nurhidayat. (2008). Fun Game: $\quad 5 p \quad$ Permainan Menyenangkan Di Indoor Dan Outdoor. Jakarta: Penebar Swadaya.

Robert E., S. (2011). Educational Psycology. $5^{\text {th }}$ ed. Boston: Allyn and Bacon.

Thomas L., G \& Jere E., B. (1990) Educational Psychology. New York: Longman.

W. S. Winkel. (2004). Psikologi pengajaran. Yogyakarta: media Abadi.

Wijaya K \& Dedi D. (2001). Mengenal Penelitian Tindakan Kelas. Jakarta: Indeks 